\title{
ENERGY BALANCE CALCULATIONS FOR THE ABLATION PERIOD 1982 AT VERNAGTFERNER, OETZTAL ALPS
}

by

\author{
HEIDI ESCHER-VETTER
}

GSF-Institute for Radiohydrometry, Ingolstădter Landstr. 1, D-8042 Neuherberg, West Germany

\begin{abstract}
In this paper, some features of energy balance terms will be discussed in respect to the melting capacity available at the surface of Vernagtferner in the Oetztal Alps. The climatic pattern of summer 1982 is described, then the method of calculating individual terms (shortwave and longwave radiation balance, sensible and latent heat flux) from records of radiation, air temperature, humidity and wind. The results of these calculations are discussed for ice, firn and snow areas of the glacier. In particular the relationship between the four terms is shown for 15 July 1982, the day with highest meltwater production in 1982. These values are then compared with the maximum values of the individual terms, showing that the highest meltwater production is caused by the combination of quite high values of the individual terms, but not of the absolutely highest ones. The importance of sensible heat flux for meltwater production in 1982 is discussed: comparison between meltwater production for the whole summer and measured runoff shows reasonable accordance.
\end{abstract}

\section{INTRODUCTION}

In 1974 the Sonderforschungsbereich 81 at the Technische Universitat Munchen was founded. Its first Teilprojekt, called "Runoff in and from glaciers", was installed to develop a glacier discharge model, which would make it possible to compare measured with calculated runoff on a time scale of hours. This required an energy balance model from which meltwater production on the glacier surface could be calculated. Basic meteorological parameters had therefore to be recorded continuously over the whole ablation period with a resolution time of some minutes in places quite near to the glacier.

For this purpose, the site of the gauging station "Pegelstation Vernagtbach" (2640 m a.s.1.) was chosen. Here, total runoff from the catchment area of Vernagtferner is recorded: the area comprises Vernagtferner/Oetztal Alps, Austria $\left(46^{\circ} 52\right.$ 'N, $10^{\circ} 49$ 'E, $\left.9.5 \mathrm{~km}^{2}, 2740 \mathrm{~m}-3633 \mathrm{~m}\right)$ and its forefield $\left(2.0 \mathrm{~km}^{2}\right.$, $2640 \mathrm{~m}-2740 \mathrm{~m})$. For the whole region, a Digital Terrain Model (DTM) with a mesh width of $100 \mathrm{~m}$ allows the calculation of height gradients of meteorological parameters from the measuring place to any site on the glacier.

Thus measuring and recording instruments for global radiation, longwave radiation, air temperature, relative humidity, precipitation, wind speed and direction were set up at the Pegelstation Vernagtbach. The measurements, taken from May to October, are backed by pictures from two automatic cameras which overlook more than $90 \%$ of the glacier area, and photograph Vernagtferner once a day; by these the distribution of newly fallen snow, older snow, firn and ice are recorded.

\section{CLIMATIC PATTERN OF THE SUMMER MONTHS 1982}

Figure 1 shows 5-day (6-day for 25-31 July and 25-31 August) averages respectively sums for global radiation, air temperature and precipitation. The highest mean of global radiation (solid line) was recorded 1 to 5

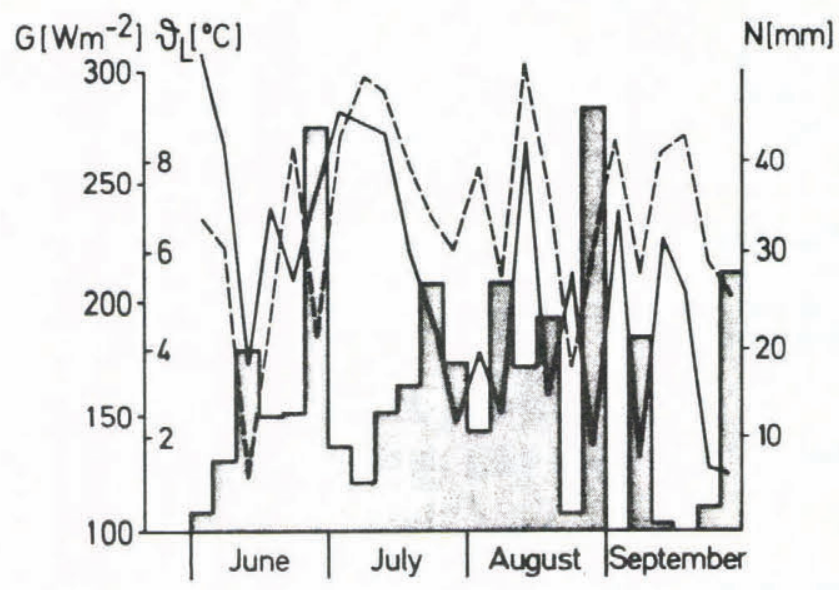

Fig.1. 5-day means of global radiation (solid line), air temperature (dashed line) and sums of precipitation (step-function) from 1 June to 30 September 1982, measured at the Pegelstation Vernagtbach $(2640 \mathrm{~m})$.

June. Between 11 and 15 June it dropped to nearly half the value of the beginning of the month, but rose again at the end of June, staying fairly constant during the first three weeks of July. In August and September, the variation between five days spells is larger again. The highest daily mean was observed on 30 June, with $342 \mathrm{Wm}^{-2}$.

Air temperatures (dashed line) are high at the beginning of June, but drop almost to zero between 11 and 15 June. This is important, as precipitation (step function) was relatively high in these days. Therefore, most of the precipitation falls as snow and not as rain. On the other hand, the generally high air temperatures from July to September indicate that nearly all precipitation was liquid during these months. The highest daily mean air temperature of $12.1^{\circ} \mathrm{C}$ is found on 4 September; highest precipitation was on 28 August with a total of $26 \mathrm{~mm}$ for the day.

Compared with values for the years 1978 to 1981 , 1982 shows medium to low global radiation, very high air temperature - especially in June, July and September - and relatively high precipitation, with the largest amounts in August.

\section{CALCULATION METHOD FOR ENERGY BALANCE TERMS}

The terms of the energy blance for each grid point of the DTM were evaluated by the folloiwng equation;

$$
\begin{aligned}
& (1-a) \cdot G+A-\sigma T_{0}^{4}+\alpha_{1}\left(v_{1}-v_{o}\right)+\alpha_{1} \frac{.623 \cdot r}{p \cdot c_{p}}\left(e_{1}-E_{o}\right)+S=0 \\
& S B K+S B L+V+V+S=0
\end{aligned}
$$


radiation of the atmosphere, $\sigma=$ Stefan-Boltzmann's constant, $T_{0}=$ (absolute) temperature of the surface, $\alpha_{1}=$ heat transfer coefficient, $v_{1}=$ air temperature at $2 \mathrm{~m}$ above ground, $v_{0}=$ (relative) temperature of the surface, $r=$ heat of evaporation, $p=$ air pressure, $c_{p}=$ specific heat of the air, $e_{1}=$ water vapor partial pressure at $v_{1} E_{0}=$ water vapor saturation pressure at $v_{0}, S B K=$ shortwave radiation balance, $\mathrm{SBL}=$ longwave radiation balance, $\mathrm{L}$ = sensible heat flux, $\mathrm{V}=$ latent heat flux, $\mathrm{S}=$ resulting melting energy.

All the terms are positive, when they tranfer energy to the surface; with the exception of $A$ and $\alpha_{1}$, all the parameters are determined at each grid point of the DTM. This means that albedo is evaluated according to the surface conditions; global radiation is transformed with a radiation distribution model which considers the exposure of the slopes and the shadowing effects of neighbouring mountains. Air temperature is reduced with the aid of a temperature gradient as described by Escher-Vetter (1980). In the same paper, the radiation distribution model is described as well as the method to determine $e_{1}$ and $p$ for each grid point.

Melting energy will be available, if the sum of SBK, SBL, L and V is positive. But what happens when the sum is negative? There are two possibilities. If there is any liquid water at the glacier surface, it will freeze and thus release its latent heat. If there is no water, or if all of it is frozen, the glacier will get colder. This cooling process has been taken into account after our first calculations of energy balance terms for the year 1979 (Baker and others 1982). These calculations showed good results for melting periods, but rather large discrepancies between measured and calculated run-off during times without melting. The results, discussed in this paper, show a further change in the calculation process: freezing of water is assumed to compensate the positive values of $S$, which remain after lowering the surface temperature. Therefore, the "negative" melting values are summed up during the night or during spells of bad weather. When there is energy available at the glacier surface again, it is first used to warm the glacier until all the energy loss has been compensated.

These calculations are done at every grid point, starting at 1 June 1982. Thus, the model becomes a step-to-step iteration for each grid point, as the surface temperature is calculated out of the negative sum of radiation balance, sensible and latent heat flux of the previous time step, according to a slightly modified formula given by Ambach (1955), and the refreezing takes place at the same grid point, where energy is lost from the surface.

These half-hourly grid point values of the terms as the time step is half an hour in this model - are then averaged over areas of more-or-less uniform surface structure. These areas are: the ice area, the firn area close to the ice area and the upper part of the glacier with firn or old snow at the surface. They were determined as follows. At each grid point, a decision was made whether there was ice visible on the photo of each individual day. The firn area close to the ice area was assumed to lie between the upper margin of the ice area and a line lying approximately $50 \mathrm{~m}$ above the elevation of the equilibrium line of the year before. In 1982 this assumption led to some difficulties, as already at the beginning of August all the area below the equilibrium line of 1981 was free of snow. Therefore, the margin between firn and snow area had to be moved to ever higher regions of Vernagtferner; at the end of the ablation season, about $40 \%$ of the glacier surface belonged to the ice area, another $20 \%$ formed the firn area, and only the rest belonged to the snow area.

It may be noticed that the distinction between firn area and snow area is made mainly out of mass balance considerations, as it is quite difficult to distinguish snow from firn in the photographs.

\section{DISCUSSION OF THE RESULTS}

Due to space problems, it is possible only to discuss some typical features of the terms in the three parts of the glacier. Firstly, we will look at the day with highest meltwater production during the summer. This was 15 July. It lies in the period with high global radiation, very high air temperatures and low precipitation (s. Figure 1). Table 1 gives the values of the components of Equation 1 for the three areas:

TABLE 1. COMPONENTS OF ENERGY BALANCE TERMS FOR ICE, FIRN, SNOW AND TOTAL AREA OF VERNAGTFERNER ON 15 JULY 1982.

$\begin{array}{lcccccc} & \begin{array}{c}\text { SBK } \\ \mathrm{Wm}^{-2}\end{array} & \begin{array}{c}\mathrm{SBL} \\ \mathrm{Wm}^{-2}\end{array} & \begin{array}{c}\mathrm{L} \\ \mathrm{Wm}^{-2}\end{array} & \begin{array}{c}\mathrm{V} \\ \mathrm{Wm}^{-2}\end{array} & \mathrm{Wm}^{-2} & \mathrm{~m} \\ \text { Ice } & 207 & -21 & +76 & -6= & & \\ \text { Firn } & 133 & -21 & +71 & -11= & =172 & 66 \\ \text { Snow } & 135 & -21 & +58 & -22= & 150 & 39 \\ \text { Total } & 144 & -21 & +65 & -16= & 172 & 44\end{array}$

The most dominant feature is the high value of the shortwave radiation balance in the ice area, which is caused by the high absorption factor 0.7 of ice. The value of SBK for the total glacier shows, however, that it is dominated by the radiation absorption in the firn and snow area.

The very small value of $-6 \mathrm{Wm}^{-2}$ for latent heat flux indicates that at least for some hours there must have been condensation on the ice surface. If one looks at Figure 2, which gives diurnal changes of the four components over ice for this day, one sees that in the

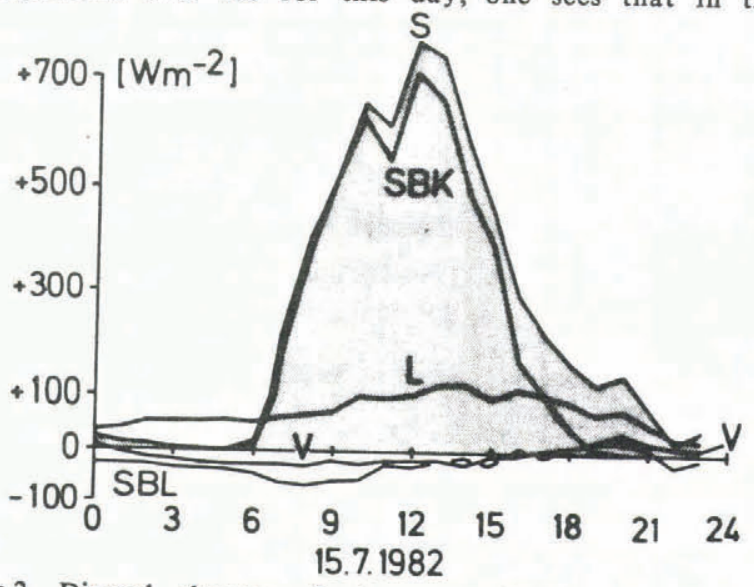

Fig.2. Diurnal changes of shortwave (SBK) and longwave (SBL) radiation balance, sensible (L) and latent (V) heat flux and resulting melting energy (S) for the ice area of Vernagtferner on 15 July 1982.

evening the latent heat flux is nearly as high as the sensible one. By that, the small negative values of SBL later in the evening are compensated, resulting in melting conditions at the ice surface all the day long.

In the firn area, melting conditions prevail during the whole day, too; only in the highest part of Vernagtferner no melting takes place between $2: 30$ and 6:30 am. The daily ablation sums (last column) seem quite reasonable for a hot, sunny, not altogether cloudless day.

It would be wrong now to conclude that these amounts of the single terms should be the highest ones, observed during the summer. It is only the combination of them which makes the available melting energy so high. This can easily be seen by the comparison of the values of 15 July with the highest amounts of SBK and L. For SBK these values are given in Table 2.

TABLE 2. DATE AND AMOUNT OF THE HIGHEST VALUES OF THE SHORTWAVE RADIATION BALANCE FOR ICE, FIRN, SNOW AND TOTAL GLACIER SURFACE IN THE ABLATION PERIOD 1982.

$\begin{array}{lllll}\text { Ice } & 237 & \mathrm{Wm}^{-2} & \text { on } 30 & \text { June } \\ \text { Firn } & 148 & \mathrm{Wm}^{-2} & \text { on } 17 & \text { July } \\ \text { Snow } & 146 & \mathrm{Wm}^{-2} & \text { on } 17 & \text { July } \\ \text { Total } & 163 & \mathrm{Wm}^{-2} & \text { on } 12 & \text { August }\end{array}$


These values, too, reflect the dominating role of albedo. Only in the ice area, the day with the largest global radiation, 30 June, shows the highest shortwave radiation balance for this area and the ablation period. As the ice area is only $10000 \mathrm{~m}^{2}$ in extent, however, this does not contribute in any significant way to the shortwave radiation balance of the total glacier, which is only 67 $\mathrm{Wm}^{-2}$ for this day. This low amount reflects the quite high albedo of newly fallen snow - $80 \%$ - on practically the whole glacier surface, whereas in the middle of July, firn and older snow are visible in the upper parts of Vernagtferner, reflecting only $55 \%$ of global radiation. The highest value of SBK for the total glacier surface, on 12 August, is caused by the combined effect of a rather large ice area $-249.10^{4} \mathrm{~m}^{2}$ - with a not-too-low global radiation $\left(299 \mathrm{Wm}^{-2}\right)$.

The highest values of sensible heat flux are calculated on 6 July for the whole glacier. This is caused by a mean daily air temperature of $10.6{ }^{\circ} \mathrm{C}$ and an average wind velocity of $7.1 \mathrm{~m} / \mathrm{s}$. They amount to

$\begin{array}{cccccc} & \text { Ice } & \text { Firn } & \text { Snow } & \text { Total } & \\ \text { L } & 126 & 117 & 94 & 105 & \mathrm{Wm}^{-2}\end{array}$

which shows that the highest values of $L$ can reach nearly the same amount as SBK. This demonstrates the extraordinarily high values of sensible heat flux in 1982, which are quite opposite to normal melting conditions on alpine glaciers, when approximately $60 \%$ to $80 \%$ of melting is caused by the radiation balance. The figures in Table 3 show this dominance quite clearly, although they were calculated as averages over the whole glacier.

TABLE 3. COMPONENTS OF ENERGY BALANCE TERMS FOR THE SUMMER MONTHS OF 1982 (MEAN VALUES FOR THE TOTAL GLACIER).

$\begin{array}{lrrrrrrr} & \begin{array}{r}\text { SBK } \\ \mathrm{Wm}^{-2}\end{array} & \begin{array}{c}\mathrm{SBL} \\ \mathrm{Wm}^{-2}\end{array} & \begin{array}{c}\mathrm{L} \\ \mathrm{Wm}^{-2}\end{array} & \begin{array}{c}\mathrm{V} \\ \mathrm{Wm}^{-2}\end{array} & & W^{-2} & \mathrm{~mm} \\ & & & & & & & \\ \text { June } & 48 & -21 & +21 & -50 & = & 9 & 70 \\ \text { July } & 101 & -15 & +53 & -33 & = & 95 & 762 \\ \text { August } & 90 & -20 & +36 & -29 & = & 78 & 624 \\ \text { Sept. } & 89 & -38 & +43 & -42 & = & 53 & 409\end{array}$

Comparing $\mathrm{L}$ with $\mathrm{SBK}+\mathrm{SBL}+\mathrm{V}$, one sees that approximately half the melting energy in July and August is delivered by $L$; in September, sensible heat causes about $80 \%$ of $\mathrm{S}$ !

The last two columns of Table 3 show the monthly sums of ablation in $\mathrm{mm}$ and their energetic equivalents in $\mathrm{Wm}^{-2}$. In June, most of the melting occurs in the forefield. July shows the highest ablation rate not only for 1982, but for all the previous years. This high ablation was the main reason why 1982 showed the highest runoff of all years from 1974 to 1983. A check on the reliability of this data can be done in comparing it to the measured runoff. In 1982, this value amounted to $2.37 \cdot 10^{7} \mathrm{~m}^{3}$. From this amount, the runoff in spring, which results from melting in the forefield, has to be subtracted as well as runof $\mathrm{f}$ wich is caused by liquid precipitation on the ice surface and the forefield: a value of $2.08 \cdot 10^{7} \mathrm{~m}^{3}$ results. As the calculated melting capacity lies at $1.87 \cdot 10^{7} \mathrm{~m}^{3}$, it is about $10 \%$ smaller than the measured one. This can be regarded as a quite good accordance.

\section{ACKNOWLEDGEMENTS}

This work was supported by the Deutsche Forschungsgemeinschaft within the framework of the Sonderforschungsbereich 81 .

\section{REFERENCES}

Ambach W 1955 Über den năchtlichen Wărmeumsatz der gefrorenen Gletscherfläche. Archiv für Meteorologie, Geophysik und Bioklimatologie A, 8(4): 411-426

Baker D, Escher-Vetter H, Moser H, Oerter H, Reinwarth O 1982 Aglacier discharge model based on results from field studies of energy balance, water storage and flow. IAHS Publ. 138: 103-112
Escher-Vetter H 1980 Der Strahlungshaushalt des Vernagtferners als Basis der Energie-haushaltsberechnung zur Bestimmung der Schmelzwasserproduktion eines Alpengletschers. Wissenschaftliche Mitteilung aus Meteorologisches Institut, Universität München 39 